\title{
WAIVER OF RIGHTS AND STATE PATERNALISM UNDER THE EUROPEAN CONVENTION ON HUMAN RIGHTS
}

\author{
Olivier De Schutter, Professor of Law at the Catholic University of \\ Louvain (Belgium)
}

\section{INTRODUCTION}

The extension of the scope of applicability of the European Convention on Human Rights to the relationships between private parties, inaugurated in the 1981 landmark judgment in the Young, James and Webster case, ${ }^{1}$ situates the conflict between the logic of fundamental rights and the logic of the market at the centre of the difficulties raised by the application of this instrument. The question of the waiver of rights, that is, of whether the individual bearer of rights may dispose of his fundamental right as he pleases, becomes of decisive importance in this context. The logic of the market is, indeed, favourable to admitting such a waiver. Such an authorization - which, one could say, seems to follow from a conception of the individual right as the private property of the right-holder - appears at first glance to enlarge the range of choices open to the individual, and thus, the utility of the rightholder: to the economist, (insofar as the individual has the choice whether or not to waive his right, and thus, whilst having the liberty not to exercise the right or not to seek its vindication, is not under an obligation to do so), the individual is better off in a context where the waiver of rights is authorized than in a context where such a waiver is prohibited. On the other hand, in the logic of fundamental rights, the possibility of waiver may appear instead as a threat. Such a possibility amounts to the commodification of the right, which becomes a negotiable good, the value of which is made dependant on the laws of offer and demand.

In this article, I intend to discuss the status recognized to the waiver of rights in the case law of the European Court of Human Rights, which, I believe, remains a doctrine in a confused state - a practice devoid of a theory. Much of the confusion, however, may be attributed to the failure to distinguish

1 Eur. Ct. H.R., Young, James and Webster v United Kingdom Case, Judgment of 13 August 1981, Series A No. 44, § 49: "Although the proximate cause of the events giving rise to this case was [an agreement between an employer and trade unions], it was the domestic law in force at the relevant time that made lawful the treatment of which the applicants complained. The responsibility of the respondent State for any resultant breach of the Convention is thus engaged on this basis". See generally, inter alia, A. Clapham, "The 'Drittwirkung' of the Convention", in: R. St. McDonald, F. Matscher \& H. Petzold, The European System for the Protection of Human Rights (Martinus Nijhoff, Dordrecht-Boston-London, 1993) p 163; A. Clapham, Human Rights in the Private Sphere (Oxford, Clarendon Press, 1993); A. Drzemczewski, "The European Human Rights Convention and Relations Between Private Parties”, Neth. I.L.R., 1979, p 163. 
clearly between two questions. ${ }^{2}$ Although both of these questions may be said to relate to the conflict between the respective logics of the market and of fundamental rights, the conflict develops, in each case, in quite distinct fashion. These two questions may be summarized as such:

(a) The first question is whether a Contracting State may avoid being found in violation of the Convention by invoking the fact that the individual applicant, although she now asserts that her rights under the Convention have been violated, had in fact consented to the treatment complained of. In such a circumstance, the question put before the European Court of Human Rights is that of the existence, vel non, of a privilege $e^{3}$ to waive a right guaranteed by the Convention. The State relies on the existence of such a privilege to escape his international responsibility for the situation complained of.

(b) The second question is whether a Contracting State may be held responsible, not only for having violated the rights set forth in the Convention, but also for having violated what the individual applicant asserts is her right not to have imposed upon her the benefit of a right which she resents as burdening her, and which she would prefer to barter away or simply to sacrifice. The right to waiver is asserted, here, not by the respondent State, but by the individual applicant; instead of it being diminished, the international obligation of the State under the Convention is duplicated: not only is the State obliged to respect each right stipulated in the Convention, it also must respect the right of the individual right-holder not to have the guarantee of the right imposed upon her.

A coherent theory of waiver under the Convention must begin with such a distinction, between these two hypotheses where the question of waiver arises $^{4}$ - either as invoked by the State (a), or as asserted by the individual (b). For example, a statement by the European Commission on Human Rights that a protest strategy by prisoners involving "self-inflicted

${ }^{2}$ It does not seem to me that $\mathrm{Ph}$. Frumer completely avoids the confusion, in an otherwise excellent thesis to which I am much indebted: La renonciation aux droits et libertés dans le système de la Convention européenne des droits de l'homme, thèse de doctorat, Université libre de Bruxelles, 1999.

3 The distinction between these two hypotheses and the terminology used to describe it are inspired by my reading of W. N. Hohfeld, "Some Fundamental Legal Conceptions as Applied in Judicial Reasoning", 23 Yale L. J. 16 (1913).

4 Perhaps one could identify a third function of waiver in the system of the European Human Rights Convention, which seems irreducible to the two main functions described here, but is of marginal importance: the waiver by the right-holder may serve as a means to estimate the adequacy of the reparation by the State authorities of the consequences of a measure found to be in violation of the Convention, thus dispensing the European Court of Human Rights from granting a just satisfaction to the aggrieved individual. See the Neumeister v Austria Case, Judgment of 7 May 1974 on just satisfaction (previously Art. 50 ECHR), following the judgment of 27 June 1968 on the existence of a violation, § 40: "In his request of 26 May 1972 for pardon, he indicated that remission of the remainder of his sentence would be the best possible form of reparation, given that the wrong suffered was by its nature incapable of being wiped out; so sure was he of this that he stated that he would be prepared to waive, if he were accorded a pardon, all his claims for compensation against the Republic of Austria ... . The opinion he expressed of his own accord at that time retains its value; it confirms the just character of the measure taken in Austria in favour of the applicant". 
debasement and humiliation to an almost sub-human degree" cannot engage the responsibility of the respondent Government, which situates us under the privilege to a waiver (a) ${ }^{5}$, may not be interpreted to imply that there can be found under article 3 of the Convention a right to engage in self-destructive practices which, if they were inflicted by State authorities, would amount to an inhuman or degrading treatment (b). Nor can the oft-quoted statement by the European Court of Human Rights that

"neither the letter nor the spirit of this provision (article $6 \S 1$ of the Convention) prevents a person from waiving of his own free will, either expressly or tacitly, the entitlement to have his case heard in public (. . .). However, a waiver must be made in an unequivocal manner and must not run counter to any important public interest"6,

be taken to mean that, under article $6, \S 1$, of the Convention, there exists a right to have one's case heard behind closed doors. In both these examples, the State invokes the existence of a privilege with the applicant to waive his right under the Convention, to diminish or simply escape its international responsibility: these examples do not even raise the question of whether or not the Convention grants a right to waiver to those to whom it grants fundamental rights.

In the following sections, I shall examine, first, the nature of the privilege to waive the rights set forth in the Convention, as invoked by the respondent State (II), and secondly, whether the Convention, when it confers a right to the person under the jurisdiction of the State party to the Convention, at the same time recognizes the right of that person to waive the right conferred upon her, not in the large but also too vague sense of not using it, but in the precise sense of exchanging it against an advantage to which the right-holder attaches more value than to the preservation of her fundamental right itself (III). It may be useful to announce, from the outset, the conclusions which I have been led to: although a privilege to waive the rights stated in the

5 According to the McFeeley decision, the protest by the prisoners "cannot derive any legitimacy or justification from the Convention and cannot be attributed to any positive action on behalf of the respondent Government. Thus the Commission is of the view that the undoubtedly harsh conditions of detention, which developed from the applicants' decision not to wear prison uniform or use the toilet and washing facilities provided and other self-imposed deprivations associated with their protest, cannot engage the responsibility of the respondent Government"(Eur. Comm. HR, Mc Feeley v United Kingdom, Appl. № 8317/78, YB ECHR, vol. 23, 1980, 256, 322).

6 Hakansson and Sturesson v Sweden case, Eur Ct HR, Series A No 171-A (1990), § 66 (for a commentary, J.-Fr. Flauss, "De la renonciation à la publicité des débats dans le cadre de la Convention européenne des droits de l'homme", Les Petites Affiches, 1991, $\mathrm{n}^{\circ} 130$, p. 20). See more recently, for a reaffirmation of the validity of this case-law, the Voisine v France case, Eur Ct HR (8 February 2000), §32. In the Le Compte, Van Leuven and De Meyere Case, the Court had already noted in its 23 June 1981 judgment, after concluding that Article 6 of the Convention was in principle applicable in the circumstances of the case: "Admittedly, neither the letter nor the spirit of Article 6 par. 1 (art. 6-1) would have prevented them from waiving this right of their own free will, whether expressly or tacitly ... ; conducting disciplinary proceedings of this kind in private does not contravene the Convention, provided that the person concerned consents." $(\S 59)$. 
Convention may be said to exist, there may be found in this instrument no right to waiver, at least absent exceptional circumstances which I shall examine in more detail below. As a result, although the Convention does not guarantee against the commodification of the rights it lists, it leaves the Contracting States free to take measures against the risks such a commodification may entail. This, however, as we will soon discover, is a much too crude characterization of a situation eminently complex in fact.

\section{Waiver as a privilege}

As must be already apparent to the reader from the examples above, a State Party to the Convention may in principle escape its international responsibility by invoking the fact that the individual applicant has waived the right afforded to him by this instrument. The principle may be read as implicit in the requirement of Article 34 of the Convention that the individual applicant must be a "victim" of the violation complained of. More precisely, it may be deduced from the rule according to which, if the direct victim of the violation is capable of filing the application in his own name, no other person - even when that other person, organization or parent, has a legal interest in obtaining from the European Court of Human Rights a judgment finding that a violation has occurred - may substitute himself to the victim, whose wish not to file a complaint with the Court must be respected, at least in the absence of pressure or duress on the victim not to act against the State. ${ }^{7}$ The procedural argument, however, is not totally convincing. For, to the doctrine just stated, it may well be responded that, once an application has indeed been lodged with the organs in charge of the Convention, these organs may continue to examine the case, even when the individual applicant expresses his wish that an end be put to that examination. $^{8}$ This latter practice, codified to some extent in the rules relating to friendly settlement under the Convention ${ }^{9}$, suggests the existence of a "public order" dimension to the Convention: indeed, it may be interpreted as witnessing to the fact that, in the system of the Convention, the rights and freedoms set forth are not a purely private matter, left at the disposal of the right-holders to whom they are recognized ${ }^{10}$.

Nevertheless, it may be argued, both from the fact that a victim of a violation of the Convention may not be forced to act against the State responsible for

${ }^{7}$ See, eg, for an application of the rule leading the Court to deny the status of "victim" to shareholders of a company which, although in the process of liquidation, nevertheless had not ceased to exist as a legal person, the Agrotexim and others v Greece Case, Judgment of 24 October 1995, esp. § 68 where the Court notes that the company was at the time of the violation "represented by its two liquidators, who had legal capacity to defend its rights and therefore to apply to the Convention institutions, if they considered it appropriate".

8 See, eg, Eur. Ct. H.R., Tyrer v United Kingdom Case, Judgment of 25 April 1978, Series A No. 26, §§ 24-27.

9 On this, O. De Schutter, "Le règlement amiable dans la Convention européenne des droits de l'homme: entre théorie de la fonction de juger et théorie de la négociation", in: Les droits de l'homme au seuil du troisième millénaire (Brussels, Bruylant, 2000) 225.

${ }^{10}$ F. Sudre, "Existe-t-il un ordre public européen?", in: P. Tavernier (ed.), Quelle Europe pour les droits de l'homme? La Cour de Strasbourg et la réalisation d'une 'union plus étroite' (Brussels, Bruylant, 1996) 39. 
the violation and from the case-law of the European Court of Human Rights, that the existence of a privilege to waiver may not as a matter of principle be excluded, thus making it possible for the respondent State to invoke the fact of the waiver to request from the Court a statement of non-violation. Moreover, the existence of a privilege to waiver, thus understood, is not limited to the cases where the individual applicant has, in fact, a right to waiver, as for example when he invokes his right to respect for private life to request closed proceedings in his case. However, the principle, that a privilege to waiver exists and must be taken account of in the evaluation of the international responsibility of the State, is limited in three important ways. In the following paragraphs, I consider with the other two the second limitation (that a privilege to waiver would be nonexistent with respect to some rights recognized under the Convention because of their fundamental character), notwithstanding my scepticism.

\section{Waiver and Individual Autonomy}

It should first be noted that the respondent State may not invoke the privilege to waiver simply because the individual, by choosing to act otherwise, could have escaped the situation which led to the violation complained of before the European Court of Human Rights. If such a reasoning were to be followed in all circumstances, the result would be to shrink the autonomy of the individual, that is, the possibility left to the individual, not only to be protected against the violations of his rights guaranteed to him by the Convention, but also to seek his self-fulfilment in the exercise of his freedom to act even when he is not exercising a fundamental right. ${ }^{11}$ In the Dupuis Case, which may serve as a perfect counter-example, the applicant, although opposed to military service, had not requested the status of conscientious objector, and had moreover waived the exemption from military service when such an exemption was granted to him. Thereafter, when charged for desertion, the applicant complained that the military courts lacked the independence and impartiality required by Article 6 of the Convention. However, the European Commission of Human Rights reasoned that "by adopting this attitude, the applicant made a choice which implied that his case would be referred to the military courts .... Bearing in mind the applicant's attitude, he cannot complain of a situation which he himself contributed to bringing about and cannot therefore claim to be a victim of a violation of Article 6 due to the allegedly objectively partial nature of the military courts in examining the case ". ${ }^{2}$ However relevant the argument may be in the specific circumstances of that case, there is, of course, a limit to its logic. For it always is the case that, by making a different choice - by choosing a different route of action - the alleged victim of a violation of the European Convention on Human Rights could have avoided the violation he then complains of : the criminal, prosecuted under a procedure incompatible

11 As noted by Jed Rubenfeld, "the very order of things in a free society may on certain occasions render intolerable a law that violates no express constitutional guarantee" (J. Rubenfeld, "The Right to Privacy", 102 Harv. L. Rev. 737 (1989)). The notion of autonomy to which I am referring here is analogous to the one put forward by J. Raz, The Morality of Freedom, Clarendon Press, Oxford, 1986.

12 Eur. Comm. H.R., Appl. No 12717/87, O. Dupuis v Belgium, Decision of 8 September 1988, D.R. 57, p. 196, 208. 
with the requirements of the Convention, could have refrained from committing the crime; the woman, discriminated against because of the laws of marriage, could have chosen to remain single; a myriad of other examples may be easily imagined.

\section{Waiver and the Nature of Rights Waived}

It is sometimes argued that there exists a second limit to the invocation by the State of the privilege to waiver, in that the privilege may not be invoked when certain guarantees of the Convention are deemed to be of such fundamental value that the State Party to the Convention must grant them, even in circumstances where the individual applicant has knowingly acted in a fashion which could be interpreted as constituting a waiver of his rights under the Convention. The typical expression of this limit is to be found in the judgment of 18 June 1971 delivered by the Court in the "Vagrancy" Cases. The three applicants, homeless people who had been detained under the provisions of Belgian law, complained of a violation of Article 5 of the Convention, because of the lack of judicial control on the detention they had been subjected to. However, the Belgian Government argued that the three applicants, in two cases explicitly, had requested their admittance into places where they would be sheltered : thus, according to the Government, the applicants would not have been "deprived of liberty" in the meaning of Article 5. The Court remained unpersuaded :

"Temporary distress or misery may drive a person to give himself up to the police to be detained. . . . Insofar as the wishes of the applicants were taken into account, they cannot in any event remove or disguise the mandatory, as opposed to contractual, character of the decisions complained of . . . . Finally and above all, the right to liberty is too important in a 'democratic society' within the meaning of the Convention for a person to lose the benefit of the protection of the Convention for the single reason that he gives himself up to be taken into detention. Detention might violate Article 5 even although the person concerned might have agreed to it. When the matter is one which concerns ordre public within the Council of Europe, a scrupulous supervision by the organs of the Convention of all measures capable of violating the rights and freedoms which it guarantees is necessary in every case (...) [T] he fact that the applicants 'reported voluntarily' [does not] in any way relieve the Court of its duty to see whether there has been a violation of the Convention". ${ }^{13}$

The passage quoted, however, is not irreproachable. The reference to the "temporary distress or misery" of the applicants, and especially the opposition drawn between measures which are "mandatory" and others which are "contractual", seem to contradict the identification of the right to liberty as belonging to the "public order", that is, as non-tradable. Furthermore, the references to the "public order" of the Convention have been proliferating since 1971, and the expression put to far too many

13 De Wilde, Ooms and Versyp Cases ("Vagrancy" Cases ), 18 June 1971, Series A No12, § 65 . 
different uses, for it still to retain a truly useful meaning. Although the notion of "public order" appears in the case-law of the Commission ${ }^{14}$ or the Court $^{15}$ to justify these organs in setting aside the procedural restrictions to their power to find a violation of the Convention, the notion is hardly helpful when the question is not one of the jurisdiction of these organs, but whether a violation has indeed occurred or not, notwithstanding the consent of the individual to the situation adversely affecting him. In such a use of the expression, moreover, the presentation of the Convention as "an instrument of European public order" seems to argue against the establishment of a hierarchy of rights within the Convention, as this character is recognized to the instrument as a whole. ${ }^{16}$ Thus, one must be careful not to attach too much weight to statements by the organs of the European Convention on Human Rights which suggest that the rights recognized by that instrument may be hierarchized, some being more fundamental, or instituted, rather than for the sole benefit of the individual, for the benefit of the whole of society, and thus not waivable by the right-holder. ${ }^{17}$ These statements serve an essentially rhetorical function: although the waiver invoked by the State will be scrutinized more closely when the right is fundamental and instituted in the public interest, the waiver of a right thus characterized is not prohibited; and the waiver of the other rights is not permissible under any circumstance.

14 See esp Eur. Comm. H.R., Appl. No788/60, Austria v Italy ("Pfunders" Case), YB ECHR, vol. 4, 1961, p. 117, 138: “. . . the purpose of the High Contracting Parties in concluding the Convention was not to concede to each other reciprocal rights and obligations in pursuance of their individual national interests but to realise the aims and ideals of the Council of Europe, . . . and to establish a common public order of the free democracies of Europe with the object of safeguarding their common heritage of political traditions, ideals, freedom and the rule of law".

15 See, eg, the Loizidou v Turkey (preliminary objections) Case, Judgment of 23 March 1995, Series A No 310, § 93 (referring to "the special character of the Convention as an instrument of European public order (ordre public) for the protection of individual human beings").

16 It is worth emphasizing, for example, that although the right to have access to a court is traditionally considered as a right too fundamental to lend itself to being waived, both the European Commission and the European Court of Human Rights have agreed that a compulsory arbitration clause may bind the individual concerned and lead the courts to deny their jurisdiction, at least, that is, if the clause has been previously freely consented to. See, inter alia, Eur. Comm. H.R., Appl. No. 1197/61, X v Fed. Rep. of Germany, decision of 5 March 1962, YB ECHR, vol. 5, p 88; Eur. Comm. H.R., Appl. No. 10881/84, $R$ v Switzerland, decision of 4 March 1987, D.R., vol. 51, p 83; Eur. Comm. H.R., Appl. No. 18926/91 and 19777/92, Spandre and Fabri v Belgium, decision of 30 August 1993, D.R., p 179; Eur. Ct. H.R., Deweer v Belgium Case, Judgment of 27 February 1980, Series A No. 35, § 49.

17 See, eg, Eur. Comm. H.R., Appl. No. 10802/84, H. Pfeifer and M. Plankl v Austria, Rep. of the Commission adopted on 11 October 1990, § 39: “. . . even supposing that the rights in question can be waived by a defendant, the circumstances surrounding the applicant's decision deprived it of any validity from the point of view of the Convention"; Eur. Comm. H.R., Appl. No. 17358/90, M. B. v Austria, Rep. of the Commission adopted on 8 September 1994: "Although the Court in Pfeifer and Plankl indicated that it was not necessarily permissible to waive all Convention rights, the Commission finds nothing in the judgment in that case which precludes the operation of a waiver in the circumstances of the present case"; Eur. Ct. H.R., Albert and Le Compte v Belgium Case, Judgment of 10 February 1983, Series A No. 58, § 35. 
The appearance of a notion of "public order" in the case law of the Convention asks for a last commentary. It is clearly established in the caselaw of the European Court of Human Rights that the national courts are not obliged to apply the Convention ex officio: in the Ahmet Sadik Case, the Court confirmed its previous case-law, against a powerful dissenting opinion of Judge S.K. Martens, to the effect that "Even if the [national] courts were able, or even obliged, to examine the case of their own motion under the Convention, this cannot have dispensed the applicant from relying on the Convention in those courts or from advancing arguments to the same or like effect before them, thus drawing their attention to the problem he intended to submit subsequently, if need be, to the institutions responsible for European supervision". ${ }^{18}$ This doctrine would be irreconcilable with the view that, as an instrument of the European public order, the Convention must be applied by the national courts, whether the individual victim has consented to the situation imposed upon him or not : instead, the Van Oosterwijck-Ahmet Sadik line of cases concerning the local remedies rule - according to which an individual must have invoked the Convention before the national courts, at least in substance, for his application to the international judge to be admissible - strongly argues against a prohibition of waiver under the Convention, that is, it recognizes that the respondent State may invoke the abdication of the individual to escape its international responsibility. It seems therefore that the "public order" character of the Convention mentioned in the "Vagrancy" Cases not only may not serve to arrange the rights and liberties of the Convention in a hierarchical order; it also cannot be interpreted as meaning that the privilege to waiver is not recognized under the Convention, in the sense that it could not be invoked by the State, in any circumstance, to diminish its international responsibility.

\section{Waiver and Procedural Guarantees}

Whichever the recognition of the waiver as privilege in the system of the Convention, it cannot be doubted that the validity of the waiver, as invoked by the respondent State before the European Court of Human Rights, is to be decided solely on the basis of the Convention itself, and not on the basis of the criteria set forth by the national legislation of the State party. In the Bulut case, although it appeared clearly that the applicant's lawyer had not used the opportunity given to him to challenge the presence of a judge as a member of a criminal court after he was informed that the judge had taken part in the questioning of two witnesses during the preliminary investigation, the European Court of Human Rights considered - after having explicitly refused to question the finding of the national courts that the waiver was valid under Austrian law - that: "Regardless of whether a waiver was made or not, the Court has still to decide, from the standpoint of the Convention, whether the participation of [a judge] in the trial after taking part in the questioning of witnesses at the pre-trial stage could cast doubt on the impartiality of the trial court"19. However, a few paragraphs later, the Court

18 Ahmet Sadik v Greece Case, Judgment of 15 November 1996, § 33. See previously the Van Oosterwijck v Belgium Case, Judgment of 6 November 1980 (Series A No. 40), and the Cardot v France Case, Judgment of 19 March 1991 (Series A No. 200).

19 Bulut v Austria case, 22 Feb. 1996, § 30. 
appears to afford more weight to the waiver invoked by the respondent Government, when it considered that "it is not open to the applicant to complain that he had legitimate reasons to doubt the impartiality of the court which tried him, when he had [under national law] the right to challenge its composition but refrained from doing so" ${ }^{20}$. The two statements are contradictory only under a superficial reading: in fact, all the first statement means is that the validity of the waiver may not depend ultimately on the internal law of the State party to the Convention, but must be considered from the point of view of the Convention alone, although the guarantees surrounding the waiver under internal law at times appear as a condition of the validity of the waiver from the point of view of the Convention itself ${ }^{21}$; one could say, somewhat abusively insofar as the term "waiver" does not appear in the text of that instrument, that the notion receives, in the Convention, an autonomous meaning, that is, it has a definition which is not fully dependant of the categories and conditions of national law.

Thus, unsurprisingly, the "waiver" of his rights by the individual applicant which the State may invoke must respect a number of conditions progressively laid down in the case law of the European Court of Human Rights. ${ }^{22}$ It must be free, unequivocal - although it may be express or tacit -, sufficiently well informed, and "must not run counter to an important public interest". These conditions deserve a more elaborate commentary.

When it insists on the individual's "own free will", the European Court of Human Rights seems to require more than the obvious, that the consent of the individual to waive his right may not be coerced or obtained under conditions amounting to duress. Or, if one prefers: the Court seems to be attached to a realistic understanding of what coercion or duress may mean, especially in bargaining processes. ${ }^{23}$ In the Deweer case, which led to a

20 Bulut case, $\S 34$

21 Eur. Ct. H.R., Pfeifer and Plankl v Austria Case, Judgment of 25 February 1992, Series A No. 227, § 38 : the Court notes that the Government concedes that "there is no provision of Austrian law which allows for a defendant expressly to waive his right to be tried by a court whose composition is in accordance with the law, nor consequently is there any provision which defined the procedure to be followed for this purpose".

22 Eur. Commiss. H.R., Appl. No. 10802/84, Heinrich Pfeifer and Margit Plankl v Austria, Rep. of the Commiss. adopted on 11 October 1990 : "In order to be effective for Convention purposes, a waiver of procedural rights requires minimum guarantees commensurate to its importance" (§ 74).

23 It may be of interest to compare what follows with the criteria used by the Court to distinguish - in its own words - between "bearing Christian witness" and "improper proselytism": "The former corresponds to true evangelism, which a report drawn up in 1956 under the auspices of the World Council of Churches describes as an essential mission and a responsibility of every Christian and every Church. The latter represents a corruption or deformation of it. It may, according to the same report, take the form of activities offering material or social advantages with a view to gaining new members for a Church or exerting improper pressure on people in distress or in need; it may even entail the use of violence or brainwashing; more generally, it is not compatible with respect for the freedom of thought, conscience and religion of others" (Kokkinakis v Greece Case, 25 May 1993, Series A No260-A, § 48). It is noticeable that, in the distinction drawn, the offer of "material or social advantages" is equated with the exertion of "improper pressure". 
judgment of 27 February 1980, the applicant had been found to have violated an economic regulation, and his business was threatened with being provisionally closed. While he was facing trial, the applicant was offered a friendly settlement by the authority in charge of prosecuting the offence: indeed, the applicant was notified that his business would be authorized to remain open and the prosecution terminated after the payment of a sum of $10,000 \mathrm{BF}$. Mr Deweer promptly made the payment, and thus not only avoided the trial, but also did not have to close his business pending judgment on the offence which, according to the prosecutor, he was guilty of. At the same time, by effectuating this payment, he was in fact waiving his right to a court, which the European Court of Human Rights has read into article $6, \S 1$, of the Convention, as an element of the right to a fair trial. The Court expressed itself as follows on that issue:
“ In the Contracting States' domestic legal systems a waiver of this kind is frequently encountered both in civil matters, notably in the shape of arbitration clauses in contracts, and in criminal matters in the shape, inter alia, of fines paid by way of composition. The waiver, which has undeniable advantages for the individual concerned as well as for the administration of justice, does not in principle offend against the Convention ... Nevertheless, in a democratic society too great an importance attaches to the 'right to a court' . . . for its benefit to be forfeited solely by reason of the fact that an individual is a party to a settlement reached in the course of a procedure ancillary to court proceedings. In an area concerning the public order (ordre public) of the member States of the Council of Europe, any measure or decision alleged to be in breach of Article 6 calls for particularly careful review" 24 .

More interesting is, however, the interpretation that the Deweer Court gives to the requirement of an "absence of constraint" in the situation complained of. Reminded that the applicant faced the threat of a trial, which, according to the Belgian legislation applicable to the case, could lead to him being fined up to $30,000,000 \mathrm{BF}$, the Court considered that the "constraint" resided precisely in the imbalance - the "flagrant disproportion" - between the alternatives facing the applicant. According to the respondent Government, the waiver of the right to a court should be accepted, as the sum proposed as friendly settlement was particularly minor compared to the fines which could have been judicially imposed on Deweer. To this, the Court answers: "The 'relative moderation' of the sum demanded in fact tells against the Government's argument since it added to the pressure brought to bear by the closure order. The moderation rendered the pressure so compelling that it is not surprising that Mr Deweer yielded"25. This answer is paradoxical only in appearance. Indeed, the particular suspiciousness of the Court towards the proposal of settlements, implying the waiver of the right to a court, which appear too advantageous to the person concerned, simply results from the assimilation of the sum offered against the waiver to a tax imposed on the exercise of a right: the higher the sum gained by the person agreeing to

24 Deweer v Belgium, Judgment of 27 February 1980, Series A No 35, § 49.

25 Deweer case, $\$ 51$. 
waive the right ${ }^{26}$, the heavier the tax - in both cases, there is a coercion at work, and the means through which such coercion is imposed is, in the reasoning of the Court, indifferent.

Not only must the consent be free, however; it must also be informed. ${ }^{27}$ Especially in the course of legal proceedings, the validity of the waiver may depend on the presence of a lawyer, capable of informing the aggrieved individual of its possible consequences. ${ }^{28}$ In fact, legal representation not only guarantees that the consent will be informed; it also constitutes a check against pressure being exercised on the layperson. In the Pfeifer and Plankl case, the Commission reasoned thus, rejecting the argument of the Austrian Government that the applicant, by agreeing to the composition of the court before which he appeared, had waived his right to invoke its lack of objective impartiality on that basis:

". . . the presiding judge incited the applicant to waive his right to a remedy which would otherwise have been available to him. It may be left open whether in this context undue pressure was exerted on the first applicant or whether he was led into error about the legal situation. It suffices to note that the applicant was put into a difficult psychological situation when he was called to appear before the presiding judge without the assistance of his legal defence counsel, and required to give a reply immediately. In order to preserve his rights, he would have had to tell the presiding judge that he did not agree with him that the disqualification was merely a formal matter and did not justify a fear of substantive bias. It may well be that a waiver declared by the applicant in the presence of his lawyer before a judge who was not himself disqualified would have to be regarded as binding also for the

26 Of course, this sum is not that of the transactory fee. The sum gained by the person agreeing to waive his right is equivalent to the sum that person risks being fined if the case goes to court (in the Deweer case, up to 30,000,000.- BF), minus the amount of the transactory fee (in that case, 10,000.- BF): the difference between these two amounts is, in the comparison suggested, the level at which the tax is imposed for the exercise of the fundamental right at stake. This problem is logically similar to the problem of the "unconstitutional conditions" which a State may want to impose on those to whom it offers an advantage to which they have no right. Consider, for example, a grant that a State decides to offer to artists who agree not to attack the monarchy. It can be said that the artist accepting the grant has waived his right to freedom of expression. But the higher the amount of the governmental grant, the more important the pressure is exercised on the artist to waive his right. See, for a classical treatment of the question, R.L. Hale, "Unconstitutional Conditions and Constitutional Rights", 35 Colum. L. Rev 321 (1935).

27 One of the interesting conclusions Ph. Frumer is led to in his thesis which I have already cited (above, n. 2), is that positive obligations may be imposed on the State on this basis. The implications, however, remain vague.

28 On the importance of the representation by a lawyer, Eur. Comm. H.R., Appl. No. 12129/86, Hans-Dieter Hennings v Fed. Rep. of Germany, Rep. of the Commission adopted on 30 May 1991, § 58. See also the McGonnell Case, where the United Kingdom Government argued that the applicant had validly waived the right allegedly violated, as he had been represented by a lawyer before the national courts (Judgment of 8 February 2000, § 42). 
purposes of the Convention law. The Commission considers, however, that having regard to the particular circumstances in which the applicant declared his waiver, it cannot be held to be effective for the purposes of the Convention." 29

This view was shared by the Court in the judgment adopted in the same case. According to the Court, the presiding judge - who, indeed, was moreover one of the two judges whose disqualification was at stake - "on his own initiative approached Mr Pfeifer in the absence of his lawyer, .... He put to him a question that was essentially one of law, whose implications $\mathrm{Mr}$ Pfeifer as a layman was not in a position to appreciate completely. A waiver of rights expressed there and then in such circumstances appears questionable, to say the least. The fact that the applicant stated that he did not think it necessary for his lawyer to be present makes no difference. Thus even supposing that the rights in question can be waived by a defendant, the circumstances surrounding the applicant's decision deprived it of any validity from the point of view of the Convention." 30

Considered as a privilege which, although recognized initially as a prerogative of the individual right-holder, is subsequently invoked by the State defendant before the European Court of Human Rights, the waiver has the status of an exception carved into the rule that the State is answerable for all violations of the Convention which occur under its jurisdiction. Thus, unsurprisingly, the validity of the waiver depends on it being expressed by the individual with sufficient specificity, and the interpretation of the waiver is generally restrictive.

A good example ${ }^{31}$ is furnished by the recent Richard $\mathrm{v}$ France judgment of 22 April 1998. The Court was asked to decide whether the consent of the applicant - an AIDS-stricken patient awaiting compensation from the French State - to withdraw from proceedings previously brought before the Commission, after reaching a friendly settlement with the State (in January 1996), excluded him from filing a new application (in October 1996) after it appeared that the proceedings, continued before the French courts even after the applicant agreed to the settlement offered to him, were again suffering unreasonable delay. When the second application was filed, the Government asked the Court "to recognise that the friendly settlement reached with Mr Richard necessarily implied on his part the unequivocal waiver of all

29 Eur. Comm. H.R., Appl. No. 10802/84, H. Pfeifer and M. Plankl v Austria, Rep. of the Comm. Adopted on 11 October 1990, \$§ 78-79 (my emphasis).

30 Eur. Ct. H.R., Pfeifer and Plankl v Austria, Judgment of 25 February 1992, §§ 7879.

31 For another example, see Eur. Ct. H.R., M.S. v Sweden Case, Judgment of 27 August 1997, § 32. The applicant had requested compensation for what she considered to be an industrial injury; however, the Social Insurance Office had obtained her medical file from a clinic she had visited previously. The Court reject the argument of the Government that, by asking for compensation, M.S. had waived her right to confidentiality with regard to the medical data: ". . . the disclosure depended not only on the fact that the applicant had submitted her compensation claim to the Social Insurance Office but also on a number of factors beyond her control. It cannot therefore be inferred from her request that she had waived in an unequivocal manner her right under Article $8 \S 1$ of the Convention to respect for private life with regard to the medical records at the clinic" (§32). 
further proceedings against the State on account of the length of the proceedings". The Court refused to follow this suggestion, not only because of the wording of the declaration made by the applicant when he withdrew from the first proceedings, ${ }^{32}$ but also because the Court deemed it "highly unlikely that the applicant would have accepted a friendly settlement proposal that allowed the outcome of the proceedings to be delayed with impunity". 33

Tacit waiver, nevertheless, remains permissible under certain circumstances. That is, although tacit, a waiver may appear sufficiently unequivocal for it to be invoked by the respondent State to escape its international responsibility: the touchstone appears to be the "reasonableness in the circumstances of the case" of what may be required from the applicant to dispel the impression created by his silence. ${ }^{34}$ In criminal proceedings, the principle should be combined with the rule according to which the defendant cannot be expected to contribute towards his own conviction: thus, adequate safeguards must ensure that the national authorities do not escape their responsibility in the due conduct of such proceedings by simply asserting that it remains open to the accused to object to the way the trial is conducted, and thus "bring about a normal trial". 35

It is in the definition of the conditions of validity of the waiver expressed, explicitly or more tacitly, by the individual right-holder, that the European Court of Human Rights defines the exact balance between the two opposite risks involved in the recognition of a privilege to waive one's right. The simple negation of such a privilege, which would deprive of any significance the consent of the individual to the situation he complains of after the fact,

32 The applicant had agreed to "waive the right to bring any further proceedings on this account against the French State in the French and international courts"; according to the Court: "The words "on this account" expressly refer to the excessive length complained of in the first application and, consequently, to the domestic proceedings up to the point they had reached when the friendly settlement was agreed; they therefore exclude any subsequent proceedings such as those now in issue before the Court".

33 The Court continues by reiterating that "under its settled case-law, the waiver of a right guaranteed by the Convention - in so far as such a waiver is permissible must be established in an unequivocal manner (see, among other authorities, the Pfeifer and Plankl v Austria judgment of 25 February 1992, Series A no. 227, p 16 , §37) and requires minimum guarantees commensurate to its importance. Those requirements were not fulfilled in the present case". See the Richard v France (Appl. No 33441/96) Case, Judgment of 22 April 1998, §§ 42, 48-49. See also, decided the same day, the Pailot v France (Appl. No 32217/96) Case. Thus, the interpretation of the extent of the waiver is made to depend on the plausibility vel non of the consent of the aggrieved individual, in the presentation of the respondent Government, to the situation constituting the alleged violation: the less "reasonable" the consent of the individual appears to the Court, the more exacting its control will be on the reality of the alleged waiver.

34 Eur. Ct. H.R., McGonnell v United Kingdom Case, Judgment of 8 February 2000, $\S \S 44-45$. Compare for example Eur. Ct. H.R., Schuler-Zraggen v Switzerland, Judgment of 24 June 1993, Series A No. 263, §§ 56-58, with Eur. Comm. H.R., Appl. No. 16922/90, Fischer v Austria, Report of the Commission adopted on 9 September 1993, §§ 60-62.

35 Eur. Comm. H.R., Appl. No. 12129/86, H.-D. Hennings v Fed. Rep. of Germany, Report of the Commission adopted on 30 May 1991, $\S \S 49-51$. 
either would be unworkable given the many situations of life where, if the element of consent were not taken into account, the violation of a right would be assertable, or would lead to an important contraction of the scope of activities protected under the Convention, especially under Articles 8 or 10 of that instrument. At present, these articles have been used in a most extensive fashion ${ }^{36}$ precisely because the circumstances surrounding the limitation of these rights, including the circumstance of consent, may be taken into consideration in determining whether these limitations are imposed for reasons which can be deemed relevant and sufficient and are proportionate to the legitimate aim pursued. The more such a contextualism is made impossible, the more absolute, in other words, the guarantees become, and the more their scope of applicability will be restricted. On the other hand, however, the recognition of the privilege to waiver (in our terminology, of the possibility for the respondent State to invoke the consent of the individual to escape its international responsibility) puts the individual at risk, makes him vulnerable to market pressures, the coerciveness of which is not less threatening because the choice is, at least in a formal sense, voluntary.

In the words of R. Hale: "One chooses to enter into any given transaction in order to avoid the threat of something worse - threats which impinges with unequal weight on different members of society. The fact that he exercised a choice does not indicate lack of compulsion. Even a slave makes a choice. The compulsion that drives him to work operates through his own will power. He makes the 'voluntary' muscular movement which the work calls for, in order to escape some threat; and though he exercises will power and makes a choice, still, since he is making it under threat, his servitude is called "involuntary"' ${ }^{37}$. This view may be extreme, but it nevertheless serves usefully to deconstruct the natural sympathy we have for choice, because of our tendency to contrast it with coercion. Indeed, what Hale teaches is that choice is just another vehicle for coercion, and that, therefore, the question facing us is normative (which kind of freedom do we want?) rather than purely logical (in which situation do we have more choice, assuming, as a matter of course, that we prefer more choice to less choice?). At least when the waiver has its source in a bartering process where the individual gains something in exchange for his giving up of the right (for example, swift judicial proceedings or avoiding the risk of sentencing), the question is whether the individual is better off protected from the coercion exercised by market mechanisms, or rather should be left free, at least formally, to barter away his fundamental rights against some advantage more important to him; and whether the utility of the individual is all that counts, or should preferably be balanced against that of other individuals or the general interest.

36 See O. De Schutter, "La vie privée entre droit de la personnalité et liberté", Rev. trim. dr. h., 1999, p. 827.

37 R.L. Hale, "Bargaining, Duress, and Economic Liberty", 43 Colum. L. Rev. 605 (1943). 


\section{Waiver as a Right}

Quite distinct from the privilege to waiver is the right, invoked by the individual right-holder, not only to be protected against the violation of his right, but also to be free from the imposition of the benefit of the right against his own free will. Here, the individual seeks the determination from the Court that the right or freedom guaranteed to him by the Convention is, in a sense, duplicated: each primary right is accompanied by the secondary right to trade off the primary right, or, more broadly, by the secondary right "not to" receive the benefits from the primary right, except perhaps as a bargaining chip in the context of a transaction. Procedurally, the difference is significant between this hypothesis and the previous one: whilst the waiver as a privilege is invoked by the State, arguing that the individual has consented to the situation he denounces as a violation of his right, the waiver as a right is invoked by the individual, arguing against the paternalism of the State which intends to impose the benefit of an unwanted right against the very will of the right-holder. However, although the Convention recognizes a privilege to waiver - as we have seen, provided certain conditions are satisfied, the fact that an individual has consented to the situation subsequently complained of is a valid argument by which a respondent State can escape its international responsibility -, there cannot be found in the Convention a right to waiver, in the sense just stated. Such a right can be grounded neither in the general principle of liberty, according to which everything not prohibited should be permitted as constituting the exercise of a fundamental right, nor in the deduction, from positive rights (to perform an activity), of negative rights (to abstain from the activity protected). Even when the waiver operates through a contractual mechanism, by which a person disposes of his property or of his labour, this circumstance does not elevate the waiver to the status of a fundamental right protected under the Convention. The only strategy that remains available to those wishing to defend waiver as a fundamental right protected under the Convention is ad hoc: in particular circumstances, the waiver of a right $\mathrm{X}$ guaranteed by the Convention may take the form of the exercise of a right $\mathrm{Y}$, in which case, of course, the waiver ought to be guaranteed - not, that is, as waiver, but because the exercise of right $\mathrm{Y}$ can be described, alternatively, as a renunciation to the protection afforded by right $\mathrm{X}$.

\section{The General Principle of Liberty}

It seems, indeed, that there exists no general right to waiver in the European Convention on Human Rights. Of course, one could be tempted to identify such a right to waiver in the general principle of liberty, the freedom recognized the individual to do all that he wishes, provided the act causes no damage to anybody else, or remains, in Mill's phrase, "self-regarding". It is true that the existence of a fundamental right to liberty, in such sense, has been asserted at various periods by a number of constitutional courts. Most famously, the affirmation of such a right was the thrust of the doctrine of the United States Supreme Court during the so-called "Lochner era" (19051937) when, under the guise of giving a substantive content to the Due Process Clause of the Fourteenth Amendment, the Court in fact translated into constitutional law the doctrine limiting the police powers of the State to the enforcement of the maxim sic utere tuo ut alienum non laedas, according to which one must not use one's property with the purpose of violating the 
rights of others: any public intervention which goes beyond imposing respect of this basic rule of social life would constitute an intolerable, and "paternalistic", interference with individual liberty. ${ }^{38}$

Today, the constitutional doctrine which seems closest to this interpretation of a fundamental right to liberty is that which the German Federal Constitutional Court (Bundesverfassungsgericht) bases on article 2 of the Basic Law of 1949, according to which "Everybody has the right to the free development of his personality, as long as he does not violate the rights of others and does not contravene the constitutional order or moral laws" 39 . In the famous Elfe case, the Federal Constitutional Court noted that "As long as special areas of life are not protected by a basic right, the individual can refer to Article 2(1) of the Basic Law when public authorities interfere with his freedom". ${ }^{40}$ The extent to which such a protection may go is well illustrated by a case concerning a restriction imposed upon the freedom to horse-ride in woods, which was alleged to constitute an unconstitutional interference with the "general freedom to act" (allgemeine Handlungsfreiheit) embodied in Article 2(1) of the Basic Law: indeed, in that case, the Court considered that "According to the principles developed by the Bundesverfassungsgericht, Article 2(1) of the Basic Law comprehensively guarantees the right to freedom of action .... It not only protects a limited area of personality development, but rather protects every form of human activity regardless of the importance of this behaviour for the development of personality"41. Such a case-law amounts to requiring that every act by public authorities must be compatible with the principle of proportionality, or else is to be considered an infringement with the right to personal liberty, defined in turn as the right of each individual to act as he chooses unless the act violates the rights of others or infringes public order or good morals.

It is noteworthy that under German Constitutional Law, however expanded this general freedom to act - indeed, this freedom is unlimited in principle -, the public authorities are nevertheless authorized to go against the consent of the individual to a violation of his dignity, even when such consent is freely expressed and properly informed. Indeed, on the basis of Article 1(1) of the Basic Law, which states the inviolability of human dignity, the German Federal Administrative Tribunal considered that the denial of a licence to set up a peep show could be justified insofar as such a representation constituted a violation of human dignity. According to the decision:

38 The leading intellectual figure of the doctrinal landscape preceding the Lochner era, and thus responsible for preparing it, was Thomas M. Cooley, who considered that it was in the "nature of well-ordered civil society" that "every holder of property, however absolute and unqualified may be his title, holds it under the implied liability that his use of it shall not be injurious to the equal enjoyment of others having an equal right to the enjoyment of their property, nor injurious to the rights of the community" (Th. M. Cooley, Treatise on the Constitutional Limitations which rest upon the Legislative Power of the States of the American Union, Little, Brown, \& Co., Boston, $1868,7^{\text {th }}$ ed. 1883).

39 Translation from S. Michalowski and L. Woods, German Constitutional Law. The protection of civil liberties, Ashgate, Dartmouth, 1999, p 108. The excerpts that follow from the case law of the German Constitutional Court are borrowed, with slight modifications, from the same source.

40 BverfGE 6, 32 (1957).

41 BverfGE 80, 153 (1989). 
"This violation of human dignity is not excluded or justified by the fact that the woman performing in a peep show acts voluntarily. Human dignity is an objective, indisposable value, the respect of which the individual cannot waive validly .... It is insignificant for the violation of human dignity that the trader has found women who are prepared to perform, for remuneration, in a peep show .... The consent of the women concerned can only exclude a violation of human dignity if such a violation is based only on the lack of consent to the relevant actions or omissions of the women concerned. However, this is not the situation here because in the case at issue . . . the human dignity of the women concerned is violated by the exposition typical for these performances. Here, human dignity, because its significance reaches beyond the individual, must be protected even against the wishes of the woman concerned whose own subjective ideas deviate from the objective value of human dignity " 42 .

The position of German constitutional law, in sum, combines the protection of human dignity as an "objective, indisposable value", with the protection of the right of the individual to do what he chooses unless the public authorities have good reasons to limit the exercise of his liberty and impose such a limitation in full respect to the principle of proportionality. The combination of these two apparently contradictory guarantees results in providing for an exception to the principle of individual liberty, when human dignity is at stake: when such is the case, intervention by the State may be justified by the aim to protect that value, which the liberty of the individual may not lead him to sacrifice, as that value is not to be confused with something of his property or otherwise at his disposal.

The position of the European Court of Human Rights on the question of whether or not there exists in the Convention, as an element of the general liberty of the individual, a right to waive the guarantees afforded by that instrument, can be usefully compared to that just exposed. The similarity resides both in the understanding of individual liberty as a fundamental right, and in the margin of appreciation left to the public authorities in the exercise of their power, nonetheless, to impose the respect for certain values against the wish of the individual to use his liberty by waiving the rights - if this is not too paradoxical a way of putting things - imposed upon him. Although not yet complete, the elevation of the principle of liberty to the status of a fundamental right would represent the final step of a development which has led the European Commission and the European Court of Human Rights to conclude, almost a decade ago, that although it is neither possible nor necessary "to attempt an exhaustive definition of the notion of "private life", it would however be "too restrictive to limit the notion to an 'inner circle' in which the individual may live his own personal life as he chooses and to exclude therefrom entirely the outside world not encompassed within that

42 BverwGE 64, 279 (1981) (my emphasis). 
circle. Respect for private life must also comprise to a certain degree the right to establish and develop relationships with other human beings" ${ }^{43}$

Although the European Court of Human Rights has not, as yet ${ }^{44}$, gone so far as to read into Article 8 of the Convention a freedom to exercise a professional activity or to pursue a business - although such a right has been linked to the right to the free development of one's personality by the German Courts, an approach which has in turn influenced the European Court of Justice ${ }^{45}$ - the scope of activities protected under the right to privacy is nevertheless immense - indeed, it is potentially without limits. But this does not exclude the possibility for the State party to the Convention, while exercising its margin of appreciation, to impose restrictions upon the activities pursued by the individual under the guise of private life. Thus, in its Laskey, Jaggard and Brown judgment of 19 February 1997, confronted with the criminalization under English law of sado-masochistic activities performed between consenting adults, the European Court of Human Rights stated that, in its opinion, "one of the roles which the State is unquestionably entitled to undertake is to seek to regulate, through the operation of the criminal law, activities which involve the infliction of physical harm. This is so whether the activities in question occur in the course of sexual conduct or otherwise" ${ }^{46}$. After having found that the prosecution of the applicants was justified for the protection of health within the meaning of Article $8 \S 2$ of the Convention - indeed, the applicants had not suffered severe injuries from their sexual practices; but, in the opinion of the Court, the national authorities were entitled to decide to act on the basis of the "potential for harm inherent in the acts in question" 47 - the Court added: "In view of this

43 Eur. Ct H.R., Niemietz v Fed. Rep. of Germany Case, judgment of 16 December 1992, Series A No 251-B, § 29. The definition of "private life" as "the right to establish and develop relationships with other human beings" was first resorted to by the European Commission of Human Rights, in cases where at stake were the protection of the relationship between the individual applicant and a pet animal (Eur. Comm. H.R., Appl. No 6825/74, X v Iceland, D.R., 5 (1976), 86) or the right of a woman to choose to interrupt her pregnancy (Eur. Comm. H.R., Appl. No 6959/75, Brüggeman and Scheuten $\mathrm{v}$ Fed. Rep. of Germany, Report of 12 July 1977, D.R., 10 (1977), 100). The phrase was first imported into the case-law of the European Court of Human Rights by Judge S.K. Martens, in a separate opinion joined to a judgment of the Court on the expulsion of non-nationals for public order motives (Eur. Ct H.R., Beldjoudi v France, 26 March 1992).

44 See, eg, Eur. Ct H.R., Thlimmenos v Greece, 6 April 2000, nyr.

45 See, eg, Case 4/73, Nold, ECR (1974), 491.

46 Eur. Ct H.R., Laskey, Jaggard and Brown v United Kingdom, Judgment of 19 February 1997, § 43. Judge Pettiti was of the opinion that $\S 43$ should have been expanded by noting, instead of the phrasing reproduced, that the State is entitled to "regulate and punish practices of sexual abuse that are demeaning even if they do not involve the infliction of bodily harm" (see the concurring opinion of Judge Pettiti, annexed to the judgment). The French reads "régulation et sanction de pratiques d'abus sexuels même si ceux-ci n'entraînent pas de dommages corporels mais des atteintes à la dignité". The reference to human dignity, as a value which is not at the disposal of the individual because of its objective character, although dropped in $\S 43$ of the judgment, is nevertheless implicit in the statement made by the Court in the obiter dictum which it adds at the end of the decision (see below).

47 The emphasis in the excerpt is mine. This also appears to be the position of the Commission as expressed in the Report it submitted in the same case. See Eur. 
conclusion the Court ... does not find it necessary to determine whether the interference with the applicants' right to respect for private life could also be justified on the ground of the protection of morals. This finding, however, should not be understood as calling into question the prerogative of the State on moral grounds to seek to deter acts of the kind in question" 48.

It is difficult to see how the last statement quoted could be understood otherwise than as an open recognition by the Court that the consent of the individual to the violation of a right afforded to him by the Convention, however freely expressed and well-informed, does not constitute the exercise of a distinct right under this instrument. ${ }^{49}$ The relevancy of such consent is not questioned by the Court; however, the expression of consent simply feeds into the balancing of interests effectuated by the European Court of Human Rights, when it is asked to decide whether the national authorities have offered sufficient reasons for the interference complained of and whether the measures taken are proportionate to the aims pursued, in cases where the State has to justify protective measures imposed on the individual in the name of his own good, when such measures lead to a diminishment of his sphere of personal liberty : his expressed consent to a particular situation or treatment does not give birth to a new right of the individual, which he could invoke against the paternalistic pretences of the State. The deliberate agnosticism of the Court concerning the question whether the sexual activities at stake fall or not within the scope of Article 8 does not diminish the strength of that conclusion: quite the contrary, before reaching its conclusion, the Court reasons as if the activities were protected under Article 8 , which implies that the conclusion which it is led to in this case (that the State may prohibit consensual sexual activities with the aim of protecting health or morals) is not to be explained away by the debatable status of sadomasochistic activities among the activities forming a part of "private life", but implies, rather, that although consented to, a treatment may nevertheless be prohibited by the State.

Comm. H.R., Appl. Nos. 21627/93, $21826 / 93$ and 21974/93, Laskey, Jaggard and Brown v United Kingdom, Report adopted on 26 October 1995, § 60: "The Commission accepts that respect for the health and rights of others may justify a State in prohibiting activities which cause or risk causing death or serious injury or in imposing certain protective measures ( $c f$ No. $7992 / 77$ Dec 12.7.77, D.R. 14 p 234 concerning the use of motorcycle helmets and 10083/82 Dec 4.7.83 D.R. 33 p 270 concerning aiding and abetting suicide)".

48 Eur. Ct H.R., Laskey, Jaggard and Brown v United Kingdom, Judgment of 19 February 1997, § 51.

49 This appears to be common ground both for the European Court and for the European Commission, including the Members of the Commission which have expressed a dissenting opinion in the Laskey and others case. Indeed, the disagreement of Mr Loucaides, joined by six other members of the Commission, with the opinion of the majority, relied at least as heavily on the private character of the activities criminalized than on their consensual character: "If we accept that the interference in question is legitimate we inevitably open the way to Governments to intrude into persons' bedrooms to investigate allegations, for example, that spouses engage in sado-masochistic activities. Strong good reasons are necessary for such a course which in my opinion are lacking”. 


\section{From Positive to Negative Rights}

In its judgment of 13 August 1981 delivered in the Young, James and Webster case, the European Court of Human Rights had expressed the opinion, in a very cautious mode, that it does not follow from the omission in the drafting of Article 11 of the Convention of a formula guaranteeing that "no one may be compelled to belong to an association" - as stated in Article $20 \S 2$ of the Universal Declaration of Human Rights - "that the negative aspect of a person's freedom of association falls completely outside the ambit of Article 11 and that each and every compulsion to join a particular trade union is compatible with the intention of that provision". Indeed, according to the Court, "to construe Article 11 as permitting every kind of compulsion in the field of trade union membership would strike at the very substance of the freedom it is designed to guarantee". ${ }^{50}$ More than a decade later, in the Sibson and Sigurdur A. Sigurjonsson cases $^{51}$, although still refusing to pronounce itself on the question whether the "negative right of association" "is to be considered on an equal footing with the positive right", the Court confirmed that Article 11 encompassed a negative right "not to associate". More recently still, the two aspects of the right of association have been considered to be of equivalent status under Article 11, such an evolution being apparently justified by the close relationship that there exists between the right not to associate with others and the protection of freedom of thought and expression (Articles 9 and 10 of the Convention). ${ }^{52}$

Could it be argued, then, that the waiver of the rights guaranteed by the Convention should be recognized as a fundamental right under that instrument, because constituting the "negative" aspect of guarantees otherwise formulated in "positive" form? Could it be said, for example, that the "right" of an employee to sacrifice his freedom of expression is in fact embodied in Article 10 of the Convention? Could one read this clause as protecting the right "not to hold opinions", thus prohibiting a Contracting State from adopting legislation outlawing restrictions to the free speech of employees, and protecting employees from dismissal because of their exercise of freedom of expression?

Such a reading, it turns out, would be little short of absurd. First, there appears to be no logical link between the two distinct rights which the Court has read into Article 11: the "negative" right not to associate and the "positive" right of association, in fact, are so separate from one another that, in the cases just mentioned concerning freedom of association, the main question facing the Court was the opposition between these rights which,

50 Eur. Ct. H.R., Young, James and Webster v United Kingdom Case, Judgment of 13 August 1981, Series A No. 44, § 52 . See esp. A. Drzemczewski and F. Wooldridge, "The Closed Shop Case in Strasbourg", Int. \& Comp. L. Q., 1982, p 396; and J. Andrews, "The Closed Shop Case", 6 E.L.Rev. 412 (1981).

51 Eur. Ct. H.R., Sibson v United Kingdom Case, Judgment of 20 April 1993, Series A No. 258-A; Sigurdur A. Sigurjonsson v Iceland, Judgment of 30 June 1993, Series A No. 264.

52 See Eur. Ct. H.R., Chassagnou and others v France Case, Judgment of 29 April $1999, \S 103$. On the link between the negative right of association and freedom of thought and expression, see previously the Sigurdur A. Sigurjonsson Case, $\S 37$ of the judgment of the Court. 
although invoked respectively by the individual applicant (negative right) and by trade unions or the respondent State (positive right), in fact are both rights of the individual which appear to conflict with one another - the right of the individual either not to associate against his wishes, or to be effectively represented and defended by associations to which, therefore, certain advantages must be recognized. ${ }^{53}$ Secondly, and perhaps more importantly, it can easily be seen that to guarantee "negative" rights "not to" each time a "positive" right "to" is stipulated, would vastly limit the scope of the positive obligations, imposed upon the States Parties to the Convention, to prevent violations of fundamental rights from occurring even when the violation has its immediate source in the "horizontal" relationships between private parties (and, if such a violation nevertheless occurs because the preventive measures have failed, to offer a remedy to the individual victim). Consider again, hypothetically, the (negative) "right" of an employee "not to" be burdened by the benefit of Article 10 of the Convention (perhaps he asserts the existence of a right to consent to a sacrifice of his freedom of expression because he believes he will receive a higher salary if he is authorized to agree to such a clause in his employment contract): if such a right is recognized, under which conditions will it then still be possible to sue the State for refusing to adopt legislation protective of the fundamental rights of employees, that is, for not respecting the positive obligations imposed on it by the Convention?

No wonder, then, that the deduction of a negative right from a positive right recognized in the Convention has not been attempted by the European Court of Human Rights outside Article 11. In $K v$ Austria, the report of the European Commission did state that "the freedom of expression by implication also guarantees a 'negative right' not to be compelled to express oneself, that is, to remain silent". ${ }^{54}$ The statement has remained isolated; the question of whether or not a right to remain silent may be read into Article 10 of the Convention has largely become moot, in any case, since the Court subsequently agreed to discover such a right in Article $6 .{ }^{55}$ In the Johnston case, which concerned the unavailability of divorce under Irish law, the European Court of Human Rights refused to derive a right to divorce from Article 12 of the Convention, which guarantees the right to marry - arguing, ironically if one keeps in mind the reasoning of the Young, James and Webster Court, that "the Court cannot, by means of an evolutive interpretation, derive from [the Convention] a right that was not included therein at the outset, . . . [particularly] where the omission was deliberate". ${ }^{56}$ And nowhere is there to be found, in the case law, a convincing case for the

53 On this, O. De Schutter, Fonction de juger et droits fondamentaux, Brussels, Bruylant, pp 1072-1078.

54 Eur. Comm. H.R., Appl. No. 16002/90, K. v Austria, § 45.

55 Eur. Ct. H.R., Funke v France Case, Judgment of 25 February 1993, Series A No. 256-A, § 44 (recognizing "the right of anyone 'charged with a criminal offence' .... to remain silent and not to contribute to incriminating himself"). On this comparison, see the excellent commentary on the Young, James and Webster Case by R. A. Lawson and H.G. Schermers, Leading Cases of the European Court of Human Rights, Ars Aequi Libri, 1997, p 121.

56 Eur. Ct. H.R., Johnston v Ireland Case, Judgment of 18 December 1986, Series A No. $112, \S 53$. 
thesis that the protection of the negative aspect of a right should logically follow from the protection of its positive aspect.

\section{Liberty of Contract}

One may be tempted to explore yet another route by which to discover a right to waiver in the European Convention on Human Rights. ${ }^{57}$ In a large subset of cases where the question of waiver of rights arises, the alleged waiver occurs in the course of contractual relationships. Either a private party wishes to use his property or to dispose of it, by exchanging it against, among other advantages, the waiver by another of a right guaranteed to him by the Convention - for example, the employer agrees to recruit a person on the condition that she consents to some limitations brought to her right to privacy. Or an individual wishes to dispose of his labour, and beyond that, wishes to sacrifice a particular right granted to him by the Convention, if that sacrifice is required for him to have access to a reasonably well-paid employment. It is in these situations that the conflict appears most vividly between the paternalistic pretence of the State to impose the benefit of certain fundamental rights, and the preference which the individual expresses for a situation where he would be free to give up these guarantees, if not unconditionally and for an indeterminate future, at least in well-specified circumstances and during, for instance, the period of his employment.

Consider the classical case of the short person who expresses the wish to make a living as an object thrown in the infamous "dwarf-throwing" games which the French administrative courts, when the question was submitted to them, considered contrary to the requirements of human dignity. ${ }^{58}$ Although the main question faced by the French courts in these cases was framed in typically conceptual terms - it concerned the definition of what was implied in the concept of "dignité humaine" ("human dignity") - ${ }^{59}$ it seems useful to

57 For a more complete examination of this aspect, see P. Arend, "Convention européenne des droits de l'homme et liberté contractuelle", Bull. dr. h.., Luxembourg, vol. 4, 1995, p 62.

58 See Conseil d'Etat fr., 27 October 1995 (2 cases), Commune de Morsang-sur-Orge et Ville d'Aix-en-Provence, concl. P. Frydman, Rev. fr. $d r$. admin., vol. 11(6), Nov - Dec 1995, p. 1204. The first case submitted to the Conseil d'Etat, which concerned Mr. Wackenheim, had led to a decision by the Tribunal administratif de Versailles on 25 February 1992, Société Fun Productions et Wackenheim c. Commune de Morsang-sur-Orge. See the commentary by J. Fr. Flauss, "L'interdiction de spectacles dégradants et la Convention européenne des droits de l'homme", Rev. fr. dr. admin., vol. 8(6), Nov - Dec 1992, p. 1026.

59 The answer of the French courts was, summarily, that the "objectification" implied in the practice of "dwarf-throwing" was violative of human dignity. The Conseil d'Etat reasoned thus: "Considérant que l'attraction du 'lancer de nain' consistant à faire lancer un nain par des spectateurs conduit à utiliser comme un projectile une personne affectée d'un handicap physique et présentée comme telle; que, par son objet même, une telle attraction porte atteinte à la dignité de la personne humaine ...". This was also the view of the commissaire du gouvernement P. Frydman, in the opinion submitted to the Conseil d'Etat: "En effet, le but du lancer de nains - et ce qui fait tout son intérêt pour le spectateur n'est évidemment pas de lancer un poids le plus loin possible, mais de lancer avec violence et sans aucun égard pour elle une personne humaine, qui se trouve ainsi traitée comme un simple projectile, c'est-à-dire rabaissée au rang d'objet". 
insist here on the answer given in one of the cases to the argument of $\mathrm{Mr}$ Wackenheim, a dwarf person who had been recruited to perform in such "entertainments". According to Mr Wackenheim, these dwarf-throwing events were a unique opportunity for him to escape unemployment, and, indeed, to make a decent living and seek a social and professional integration that would otherwise remain, were these shows to be prohibited, beyond reach. ${ }^{60}$ The answer of the Conseil d'Etat to that presentation sounds rather tautological: the Conseil d'Etat replied simply that "le respect du principe de la liberté du travail et de celui de la liberté du commerce et de l'industrie ne fait pas obstacle à ce que l'autorité investie du pouvoir de police municipale interdise une activité même licite si une telle mesure est seule de nature à prévenir ou faire cesser un trouble à l'ordre public; que tel est le cas en l'espèce, eu égard à la nature de l'attraction en cause". The answer to the argument by the commissaire du gouvernement P. Frydman was, however, more developed.

First, he considered that at stake was more than the personal fulfilment of $\mathrm{Mr}$ Wackenheim, and the means he had chosen for his professional integration: the violation of human dignity implied in the practice would in fact affect the dwarf community as a whole, the vast majority of the members of which, according to the commissaire $d u$ gouvernement, are opposed to such a degradation of the image of dwarf persons. In these circumstances, to accept the argument of Wackenheim would be to put the interest of the individual above that of the community of which he is a member ("conduirait . . à faire prévaloir un avantage procuré à un seul individu sur la nécessité de prévenir l'humiliation d'une communauté entière"). This answer essentially begs the question. Indeed, if there exists a right to waive the right not to be subjected to inhuman or degrading treatments, then it should not be an obstacle to the right to waiver being exercised that its exercise may shock, disappoint, or be condemned by, the group to which the individual belongs. The argument seems useful only if one departs from the premise that there is no such right to waiver: it may then serve to justify the conclusion that the intervention by the municipal authorities, who took the decision to prohibit "dwarfthrowing" events, was not arbitrary or irrational, and to be explained, thus, by inavowable motives.

Secondly - and this branch of the answer to Mr Wackenheim's claim is, in fact, the most interesting - the commissaire du gouvernement was of the opinion that the dwarf could not ground his alleged right to waiver on his desire to seek personal and professional fulfillment by seizing a unique opportunity for him to be paid for an employment. Indeed, that $\mathrm{Mr}$ Wackenheim received a salary for lending himself to such "shows" was considered to be, if anything, a circumstance disfavouring his thesis :

“. . . la circonstance que la participation de l'intéressé aux spectacles incriminés donne lieu au versement d'un salaire ne nous paraît nullement de nature - nous serions tentés d'ajouter

60 The argument, based on Article 8 of the Convention, was put before the European Commission of Human Rights at a later stage; however, the Commission found that the local remedies has not been exhausted by Mr. Wackenheim, and dismissed the application (Eur. Commiss. H.R., Appl. No. 29961/96, Wackenheim v France, Dec. of 16 October 1996, unpublished). 
le contraire - à infléchir cette conclusion. De par sa nature même, la dignité de la personne humaine doit en effet être placée hors commerce et, sur un plan moral, nous croyons précisément pouvoir déceler, pour notre part, une circonstance aggravante, plutôt qu'atténuante, dans le fait qu'une personne acceptant de se prêter à une attraction à caractère dégradant le fasse à titre de prestation rémunérée dans le cadre d'une exploitation commerciale".

Why this should be so is not perfectly clear. One interpretation is that, when he waives a fundamental right against remuneration, the consent of the individual should be looked at with suspicion, the offer of remuneration exerting on the individual a form of pressure, especially if the individual is in need. The paradox this leads to - the more an exchange of his consent to waiver against something else is advantageous to the individual, the less that consent may be taken as decisive - is familiar to us: we met the same paradox in the Deweer case. Another interpretation is that it is more degrading to sell one's "right to dignity" - or, for that matter, to barter off one's fundamental right - against a monetary compensation, than it is to do so for "purer" motives, especially disinterested ones. Perhaps the reason for this condemnation could be found in the taboo it breaches, the "wall of separation" between the market and other spheres of life it creates a gap in. ${ }^{61}$

Whichever the interpretation one should give to the argument that a waiver against monetary compensation is, if anything, less acceptable even than a "gratuitous" waiver, the consequence is that the State, in such a circumstance, is recognized as having the power to deny to an individual a right to waiver which the individual vindicates (in this case, under the guise of the social and professional integration which should be available to a handicapped person), by relying on the background constraints which operate on the individual concerned. This is a disturbing implication. It means that, the less a State does to modify these background constraints, the easier it will be for it to justify a paternalistic attitude by which it denies the individual wishing to barter away his "dignity" a right to do so: it is strange, for instance, that a State not offering any professional opportunities to handicapped persons, should be recognized the power to prohibit these persons the right to take up a job contrary to their dignity, without having to prove that it has invested what it could in developing the professional integration of the handicapped. It should be possible to argue, in contrast to the French courts faced with the "dwarf-throwing" cases, that unless the State can demonstrate that acceptable alternatives are in fact available to those concerned, which do not imply a sacrifice of their dignity, it cannot reproach the individual an activity which is the only one he can perform, if he wishes to escape from the marginal status the circumstances would otherwise confine him to. As argued by Margaret Jane Radin, commenting on the case of a poor and oppressed person accepting a humiliating job: “. . . even if we think of the exchange as coerced, and not usefully characterized as an exercise of liberty, we are still left with the problem that to the desperate person the desperate exchange must have appeared better than her

${ }^{61}$ On this theme, see esp. M. J. Radin, "Market Inalienability", 100 Harv. L. Rev. 1849 (1987). 
previous straits, and in banning the exchange we haven't done anything about the straits . . . It seems to add insult to injury to ban desperate exchanges by deeming them coerced by terrible circumstances, without changing the circumstances". ${ }^{6}$

It is true, however, that the case-law of the European Court of Human Rights has never recognized the right to a professional activity as a right protected under the Convention. ${ }^{63}$ Although, in the words of the Court, "it is . . . in the course of their working lives that the majority of people have a significant, if not the greatest, opportunity of developing relationships with the outside world" 64 - which explains that the protection of Article 8 of the Convention extends to professional life - a restriction on the access to employment or to the exercise of a professional activity will only have to be justified by the national authorities if such a restriction may be argued to violate a right independently guaranteed by the Convention, for example, the right to religious manifestation, or the right to freedom of expression. ${ }^{65}$ It cannot be excluded that the entry into force of Protocol 12 to the European Convention on Human Rights, which provides for a general prohibition of discrimination independently of the other rights of the Convention, will lead the Court, in the future, to examine more stringently all the restrictions imposed by the Contracting States having ratified the Protocol on access to employment. It would be in line with the current case-law of the Court, however, as expressed most vividly in the Laskey, Jaggard and Brown case, if it decided that a State does not violate its obligations under the Convention and the additional Protocol against discrimination, by prohibiting access to employment of an individual when such an employment would imply a sacrifice of his dignity or, expressed in a less restrictive fashion, a too important restriction of his fundamental rights - a limitation which, should the individual not have consented, would undoubtedly amount to a violation.

Nor is freedom of contract protected by the European Court of Human Rights as a fundamental right, implicated, for instance, by Article 1 of Protocol 1 guaranteeing the peaceful enjoyment of possessions. In the Mellacher case, the applicants argued that rent control legislation, the effect of which was to diminish, in some cases dramatically, the rent which could be received per square metre, amounted to a deprivation of their possession, or at the very least, deprived them of "a contractual right to receive payment of the agreed rent". Indeed, the contested legislation made it possible for tenants to seek a reduction of the level of the rent to the level legislatively permitted and constituted thus, in the view of the applicants, "a statutory

62 M.J. Radin, "Justice and the Market Domain", in J. W. Chapman and J.R. Pennock (eds), Markets and Justice - Nomos XXXI, New York Univ. Press, 1989, p. 165, 182 .

63 See, eg, Eur. Ct H.R., Thlimmenos v Greece, 6 April 2000, nyr.

${ }^{64}$ Eur. Ct. H.R., Niemietz v Fed. Rep. of Germany Case, Judgment of 16 December 1992, Series A, No. 251- B, § 29.

$65 \mathrm{See}, e g$, the cases concerning the loyalty to the Constitution required from public servants in the Federal Republic of Germany : Eur. Ct. H.R., Glasenapp v Fed. Rep. of Germany Case, Judgment of 28 August 1986, Series A, No. 104; Eur. Ct. H.R., Kosiek v Fed. Rep. of Germany Case, Judgment of 28 August 1986, Series A, No. 105 ; and, more recently, Eur. Ct. H.R., Vogt v Fed. Rep. of Germany Case, Judgment of 20 November 1995, Series A, No. 323. 
inducement not to comply with the terms of a validly conducted lease and therefore violated the principle of freedom of contract". The Court observed that "in remedial social legislation and in particular in the field of rent control, . . . it must be open to the legislature to take measures affecting the further execution of previously concluded contracts in order to attain the aim of the policy adopted". It concluded: "The fact that the original rents were agreed upon and corresponded to the then prevailing market conditions does not mean that the legislature could not reasonably decide as a matter of policy that they were unacceptable from the point of view of social justice". ${ }^{66}$

The relationship of the Mellacher case to the question of the existence vel non of a right to waiver in the European Convention on Human Rights should be clear. ${ }^{67}$ The Court decides, here, that the protection afforded by the Convention to the property one has does not extend to the right to exchange that property against some other advantage, under the conditions reigning in the market. ${ }^{68}$ Perhaps one could reason by analogy: the right one has to freedom of expression or to respect of private life does not extend to the right to obtain, under the mechanisms of the market, a remuneration for the sacrifice of that right, or even for agreeing to that right being limited in some less complete way. Of course, this does not imply that it would be contrary to the Convention to consent to such a restriction; indeed, should such a consent be freely given in valid circumstances, a respondent State could argue that, therefore, it should not be held responsible for the situation that the consent led to. But that simply means that there exists, in the Convention, a privilege to waiver; it has nothing to do with a right to waive the right to the limitation of which one consented.

\section{The ad hoc recognition of certain rights to waiver}

One final comment is in order. In a limited number of circumstances, it appears that a particular use of a right $\mathrm{Y}$, recognized under the Convention, may be redescribed as constituting - or rather, as implying - a waiver of a right $\mathrm{X}$. We have already met such a circumstance: the right to remain silent, as an aspect of the right not to incriminate oneself during criminal proceedings, although it has its basis in Article 6 of the Convention, may also be said to lead to the recognition, on that limited ground, of a right "not to" express oneself, that is, of a right to waive the right to hold opinions guaranteed in Article 10. Other examples come to mind: the right to waive one's right to have one's case heard in public could be said to follow from the right to privacy of Article 8 of the Convention, when, indeed, the publicity of a case could lead to damaging the reputation of an individual or to matters personal to him being disclosed; more contentiously perhaps: could it not be argued that the right to waive one's right to life (Article 2 of the Convention), that is, to be assisted in the exercise of one's "right to die",

66 Eur. Cr. H.R., Mellacher and others v Austria Case, Judgment of 18 December 1989, Series A No. 169, §56.

67 See further J.-Fr. Flauss, "Liberté contractuelle et contrôle des loyers à l'aune de la Convention européenne des droits de l'homme", Rev. trim. dr. h., 1990, p. 387.

68 See the opinion of the Commission, as expressed in its Report adopted on 11 July 1988, § 208: "In view of the importance of housing as a basic social need it was. . . legitimate to seek to curb excesses of the free play of market forces and aim at a general moderation of the level of housing rents". 
can be deduced from the right not to be subjected to inhuman and degrading treatments (Article 3 of the Convention), when the circumstances of continued life become truly unbearable or degrading ?

Although such a strategy to discover a right to waiver in the Convention is valid as far as it goes, it is not without risk. Consider for example the famous Cruzan case, in which the United States Supreme Court gave judgment on 25 June 1990. Briefly, the question put to the Court was whether the guardians of Nancy Cruzan, a patient in a persistent vegetative state, could seek judicial sanction for their wish to terminate artificial hydration and nutrition for the patient, and whether the limits imposed by a State law, requiring clear and convincing evidence of the patient's wish to cease hydration and nutrition, should be ignored as violative of a constitutionally recognized right. In an opinion by Chief Justice Rehnquist, the Court framed the question thus: "This is the first case", the opinion stated, "in which we have been squarely presented with the issue whether the United States Constitution grants what is in common parlance referred to as a 'right to die"". ${ }^{69}$ But this is not so. At stake in Cruzan was not a hypothetical "right to die", but, more modestly, the right to refuse medical treatment. ${ }^{70}$ The distinction is not, of course, a pure matter of formulation: a person suffering from depression would have to rely on a "right to die" if she wanted to obtain from the State a form of assistance to perform suicide; she could not rely on a simple right to refuse medical treatment. In his concurring opinion to the Cruzan decision, Justice Scalia did adopt the view that the "action-inaction distinction" was "irrelevant": "Starving oneself to death is no different from putting a gun to one's temple as far as the common-law definition is concerned". Perhaps this is a faithful reading of the common law principles. But the distinction, for the purpose of constitutional law, is nevertheless a valid one, indeed it has an essential function to perform: the right to refuse food constitutes, arguably at least, an aspect of the right to privacy; but this right does not extend to "putting a gun to one's temple".

There are two distinct and correlative risks implied in the reasoning by which a right to waive right $\mathrm{X}$ (in the Cruzan example, the right to waive the right to life) is grounded in right $\mathrm{Y}$ (the right to refuse medical treatment). One error is precisely that committed by the majority opinion in Cruzan: it is to deny an implication of right $\mathrm{Y}$ because of its consequence - because of the recognition it entails, albeit in a limited way, that its exercise takes the form, in a particular circumstance, of the waiver of right $\mathrm{X}$. The symmetrical error, however, also may be easily committed: once one has agreed that the exercise of right $\mathrm{Y}$ can lead to the waiver of right $\mathrm{X}$, it is tempting, but wrong, to conclude that there exists, as a general rule, a waiver to right $\mathrm{X}$. Indeed: had the Supreme Court recognized the right of Nancy Cruzan to refuse nutrition and hydration, it would not have followed from its decision that the United States Constitution, from then on, should be read as securing

69 Cruzan v Missouri Dept. of Health, 110 S. Ct. 2841, 2851 (1990).

70 See Brennan J., dissenting in Cruzan, 110 S. Ct. 2841, 2867-2868: "The right to be free from unwanted medical attention is a right to evaluate the potential benefit of treatment and its possible consequences according to one's own values and to make a personal decision whether to subject oneself to the intrusion". 
a general "right to die", outside the particular case where such a "right" is a necessary implication of the right to refuse medical treatment.

\section{CONCLUSION}

The difficult questions raised by the waiver of fundamental rights have not been answered. All that was attempted in these pages was a clarification of issues that will have to find their solutions elsewhere. I have been arguing that, although the Convention recognizes a privilege to waiver provided a limited number of conditions obtain, there can be found in the Convention itself or in the case-law of the European Court of Human Rights no right to waiver. It should come as no surprise that both conclusions are favourable to the State: although the State may escape or diminish its international responsibility by relying on the privilege to waiver (by arguing that, as the applicant has freely consented to the situation he subsequently complains of, his application should fail for that reason), the State is not under an obligation to recognize that, duplicating the rights the Convention grants the individual, there exists a general right to waive these rights - either to sacrifice them without compensation or to trade them against something else.

The position of the State is, indeed, a comfortable one. But before a State may invoke the exercise by the individual having lodged an application against it, it must offer adequate procedural guarantees to that individual, whose choice must not be coerced, must be fully informed, and must be unequivocally expressed. Furthermore, the developments of the right to respect for private life are of such magnitude in the case-law of the Court that, in fact, in an increasing proportion of circumstances where an individual would be tempted to invoke a right to waiver, he will be able to rely, with at least reasonable plausibility, on Article 8 of the Convention. Last, and perhaps most importantly, the position of the State is advantageous only in the procedural sense, and it could turn out that we all, as individuals to whom the Convention secures rights, would be worse off, rather than better off, with a right to waiver than without such a right. It is already a fairly coercive situation where our consent to certain limitations on our rights can be reproached us, and prohibit us from suing the State for not having protected us effectively against the temptations of the market; imagine how much more in danger we would find ourselves if, tomorrow, the European Court of Human Rights were to urge the dismantling of the barriers which - in the fields of employment, trade unionism, family relationships - to this day, still separate the market from our fundamental rights, and protect us against our temptation to choose according to short-term criteria, and as interested rather than altruistic beings. 